\title{
Tinjauan Hukum Islam Terhadap Upah Pembajak Sawah di Desa Klesem Pacitan
}

\author{
M. Harir Muzakki \& Ahmad Sumanto
}

\begin{abstract}
An Overview of Islamic Law on the Ricefields Plowing Contracts in Klesem Village of Pacitan. This paper discusses the review of Islamic law regarding the contract of renting a tractor to plow the fields in Klesem Village, Kebon Agung Subdistrict, Pacitan Regency. The aim is to find out whether the practice is in accordance with Islamic law or not. In general, the wage contract in Klesem Village can be classified into the ijarah contract in Islamic law. The main principle in the ijarah contract is mutual benefit and prohibited from judging. Determination of wages must be clear which includes the amount of wages and the procedure for payment. This study finds out that, plow machine service providers often do not keep the time and ask for additional from the wages previously promised. Determination of wage changes and cancellation or termination of contracts unilaterally is certainly detrimental to the farmers. Thus, although in general the practice of renting tractors in the village of Klesem is legal according to Islamic law, there are still practices violating the principles of Islamic law.
\end{abstract}

Keyword: wage, agreement, Pacitan, farmer, Islamic law

\begin{abstract}
Abstrak: Tinjauan Hukum Islam Terhadap Upab Pembajak Sawab di Desa Klesem Pacitan. Tulisan ini membahas tinjauan hukum Islam tentang praktek pengupahan operator traktor untuk membajak sawah di Desa Klesem Kecamatan Kebon Agung Kabupaten Pacitan. Tujuannya untuk mengetahui apakah praktek tersebut sesuai dengan hukum Islam atau tidak. Secara umum, akad pengupahan di Desa Klesem dapat digolongkan ke dalam akad ijarah dalam hukum Islam. Prinsip utama dalam akad ijarah adalah saling menguntungkan dan dilarang menzalimi. Penetapan upah pun harus jelas yang meliputi besarnya upah dan tata cara pembayaran upah. Studi ini menemukan fakta bahwa penyedia jasa mesin bajak seringkali tidak menepati waktu dan meminta tambahan dari upah yang sebelumnya telah diperjanjikan. Penentuan upah yang berubah-ubah dan pembatalan atau penghentian kontrak secara sepihak semacam ini tentu saja merugikan pihak petani. Kesimpulannya, meski secara umum praktek sewa menyewa traktor di desa Klesem sah menurut hukum Islam, namun masih ada kasus-kasus yang menyalahi prinsip hukum Islam.
\end{abstract}

Kata Kunci: perjanjian, pengupahan, Pacitan, petani, hukum Islam

Institut Agama Islam Negeri (IAIN) Ponorogo

E-mail: harir_zdz06@yahoo.com,sumanto@yahoo.com 


\section{Pendahuluan}

Upah dapat didefinisikan sebagai sejumlah uang yang dibayar oleh orang yang memberi pekerjaan kepada seorang pekerja atas jasanya sesuai dengan perjanjian. ${ }^{1}$ Menurut fikih muamalah bahwa transaksi uang dengan tenaga kerja manusia disebut ujrah/upah. ${ }^{2}$ Dalam pandangan syariat Islam upah adalah hak dari orang yang telah bekerja dan kewajiban orang yang mempekerjakan untuk membayarnya. ${ }^{3}$ Upah merupakan hak dari seorang buruh sebagai harga atas tenaga yang telah disumbangkannya dalam proses produksi dan pemberi kerja wajib membayarnya.

Allah menghalalkan upah karena upah merupakan konpensasi atas jasa yang telah diberikan seorang pekerja, dan perampasan terhadap upah merupakan perbuatan buruk yang akan mendapat ancaman siksa dari Allah (Q.s. al-Talaq: 6). ${ }^{4}$ Dalam sebuah hadis, Nabi mengatakan bahwa "siapa yang akan mempekerjakan orang harus memberitahukan upahnya." Upah dibayarkan kepada para pekerja sesuai dengan kesepakatan dan manfaat yang diberikan sehingga keduanya terikat dengan suatu kontrak yang telah disepakati.

Salah satu bentuk kegiatan manusia dalam bidang muamalah adalah Ijârah yang terambil dari bentuk fi'il "ajara-yajuru-ajran". Ajran semakna dengan kata al-iwâdh yang mempunyai arti ganti dan upah. Ajran juga dapat berarti sewa atau upah. Ijârah berarti akad untuk beberapa manfaat terhadap penggantian. ${ }^{6}$ Oleh karena itu, lafaz ijârah mempunyai pengertian umum yang meliputi upah atas pemanfaatan sesuatu benda atau imbalan sesuatu kegiatan, atau upah karena melakukan sesuatu aktivitas. ${ }^{7}$

Ijârah berlaku umum atas setiap akad yang berwujud pemberian imbalan atas sesuatu manfaat yang diambil. ${ }^{8}$ Secara garis besarnya ijârah terdiri dari

${ }^{1}$ Afzalur Rahman, Doktrin Ekonomi Islam, Jilid 2 (Yogyakarta: PT. Dana Bhakti Wakaf, 1995), h. 361.

${ }^{2}$ M.B. Hendrie Anto, Pengantar Ekonomika Mikro Islami (Yogyakarta: Ekonosia, 2003), h. 224.

${ }^{3}$ M.B. Hendrie Anto, Pengantar Ekonomika Mikro Islami, h. 224.

${ }^{4}$ Artinya: "Apabila mereka (wanita-wanita) meyusui anak (kalian), maka berikanlah kepada mereka upah-upahnya".

${ }^{5}$ Jusmaliani, Teori Ekonomi dalam Islam (Yogyakarta: Kreasi Kencana, 2005), h. 195.

${ }^{6}$ Qomarul Huda, Figh Muamalah (Yogyakarta: Teras, 2011), h. 77.

${ }^{7}$ Helmi Karim, Fiqh Muamalah (Jakarta: PT Raja Grafindo Persada, 1997), h. 29.

${ }^{8}$ Terkait penjelasan ijârah bisa dilihat pada karya Muhannad A. Atmeh, and Jamal Abdel- 
beberapa hal. Pertama, apabila yang menjadi objek transaksi adalah manfaat atau jasa dari suatu benda disebut ijârah al-ain atau sewa-menyewa, seperti menyewa rumah untuk ditempati. Kedua, bila yang menjadi objek transaksi adalah manfaat atau jasa dari tenaga seseorang disebut ijârah al-zimmah atau upah-mengupah, seperti upah menjahit pakaian. ${ }^{?}$

Masyarakat Desa Klesem Kecamatan Kebonagung Kabupaten Pacitan pada umumnya adalah masyarakat menengah ke bawah. Secara umum berprofesi sebagai petani padi. Sebelum tahun 2013, para petani menggarap sawahnya secara tradisional dengan memakai alat pembajak sawah yang tenaganya dari manusia. ${ }^{10}$ Setelah tahun itu, sebagaian dari mereka mulai menggarap sawah dengan alat mesin pembajak sawah, yakni traktor. Awalnya mereka membeli mesin pembajak tersebut hanya untuk membajak sawahnya sendiri. Seiring berjalannya waktu, para petani di sekitarnya meminta sawahnya dibajak dipakai mesin mesin traktor, kemudian pemilik mesin traktor membuka jasa pembajakan sawah bagi

Rahman Abu-Serdaneh. "A Proposed Model for Accounting Treatment of Ijarah.” International Journal of Business and Management 7, no. 18 (2012): h. 49. Nursilah Ahmad, and Syazwani Abd Rahim. "Sukuk Ijarah vs. Sukuk Musyarakah: Investigating Post-Crisis Stock Market Reactions,"." International Journal of Humanities and Management Sci-ences (IJHMS) 1, no. 1 (2013). Nurul Aini Muhamed, and Rafisah Mat Radzi. "Implication of Sukuk Structuring: The Comparison on the Structure of Asset Based and Asset Backed Ijarah Sukuk." In 2nd International Conference on Business and Economic Research (2nd ICBER 2011) Proceeding, no. 2011, h, 466. Razli Ramli, and Hasleenda Onn. Islamic Hire-purchase (Ijarah Thumma Al-Bai-AiTab): The Handbook. Islamic Banking \& Finance Institute Malaysia Sdn Bhd, 2007. Mirza Vejzagic. "Ijarah Muntahia Bittamleek (IMB): A Risk Management Perspective." Merit Research Journal of Accounting, Auditing, Economics and Finance Vol. 2 (1)(2014): h. 001-007. Fahad Zafar. "Ijarah Contract: A Practical Dilemma." Journal of Islamic Accounting and Business Research 3, no. 1 (2012): h. 67-69. Remali Yusoff, and Dayang Norainie Awang Masri. "Selection Factors of the Acceptance Al-Ijarah Thumma Al Bay (AITAB) in Shah Alam." In Kertas Kerja Dibentangkan di 5th Islamic Economics System Conference (iECONS 2013), h. 4-5. Hanudin Amin. "Al-Ijarah Thumma Al-Bay Facility in Labuan Car Markets: An Application of Structural Equation Model." Labuan e-Journal of Muamalat and Society 4 (2010): h. 45-57. Dodik Siswantoro. "Analysis of the First Ijarah Sukuk Default in Indonesia: How Could It Be?.” International Journal of Islamic Banking \& Finance 3, no. 2 (2013): h. 1-15. Muhammad Haroon Ameer, and Muhammad Saud Ansari. "Islamic Banking: Ijarah and Conventional Leasing." Developing Country Studies 4, no. 9 (2014): 126-129. Namrata Gupta. "Differences in Accounting Treatment of Ijarah: A Case Study of UAE Islamic Banks." International Journal of Islamic and Middle Eastern Finance and Management 8, no. 3 (2015): h. 369-379. Abdul Jalil Jamila, Mariam, and Zuriah Abdul Rahman. "Sukuk Investment: Comparison of the Profits Obtained by Using Ijarah and Musharakah Mutanaqisah Principles with Long-Term Tenure." Qualitative Research in Financial Markets4, no. 2/3 (2012): h. 206-227.

${ }_{9}^{9}$ Amir Syarifuddin, Garis-garis Besar Fiqh (Jakarta: Prenada Media, 2003), h. 215.

${ }^{10}$ Hasil Observasi, Pacitan, 27 November 2016. 
para petani yang membutuhkannya. Hal ini menjadi usaha sampingan tersendiri untuk menambah penghasilan hidup mereka. ${ }^{11}$

Kondisi wilayah Desa Klesem berupa dataran tinggi atau pegunungan dengan model sawah terasiring. Penetapan upah jasa pembajak sawah tidak bisa didasarkan pada besarnya ukuran tanah melainkan didasarkan pada waktu. Biasanya petani memberi upah empat puluh ribu perjam terhitung mulai mesin traktor berjalan melakukan penggarukan tanah. Dengan ketentuan lain, jika di luar penggarukan maka tidak masuk dalam hitungan waktu pengerjaan. ${ }^{12}$ Menetapkan upah yang adil bagi pekerja bukan perkara yang mudah. Seringkali penyedia jasa atau pekerja meminta upah tambahan dari petani di luar kesepakatan setelah pekerjaan membajak sawah selesai.

Menurut hukum Islam, kesepakatan atau akad yang dibuat oleh petani dan penyedia jasa merupakan masalah penting dalam pembajakan sawah. Akad berfungsi untuk mengatur secara praktis hubungan pekerja majikan atau penyedia jasa dan petani yang memuat hak dan kewajiban kedua belah pihak. Prinsip dalam pembuatan akad adanya keterbukaan antara kedua belah pihak sehingga dalam suatu pekerjaan tidak bersifat spekulatif, tidak ada penipuan, dan tidak merugikan salah satu pihak. ${ }^{13}$

Penyedia jasa mesin bajak seringkali dalam membajak sawah tidak sesuai dengan waktu yang dijanjikan atau lebih mundur dari jadwalnya. Ketidaktepatan waktu pengerjaan tersebut merugikan pihak petani karena waktu penggarapan yang belum pasti. Pihak penyedia jasa dalam praktik jasa pembajak sawah di Desa Klesem telah melakukan wanprestasi atas perjanjian yang dibuat bersama. Wanprestasi dalam hukum perjanjian berarti penyedia jasa tidak melaksanakan kewajiban prestasinya atau

${ }^{11}$ Wawancara dengan Bapak Sujito, (Penyedia Jasa Pembajak Sawah, Pacitan), 11 Januari 2017.
${ }^{12}$ Wawancara dengan Bapak Sujito, (Penyedia Jasa Pembajak Sawah, Pacitan).
${ }^{13}$ Lebih jelasnya terkait akad bisa dilihat pada karya Rahmani Timorita Yulianti. "AsasAsas Perjanjian (Akad) dalam Hukum Kontrak Syari'ah.” La_Riba 2, no. 1 (2008): 91-107. Eka Nuraini Rachmawati. "Akad Jual Beli dalam Perspektif Fikih dan Praktiknya di Pasar Modal Indonesia." Al-'Adalah 12, no. 2 (2016): 785-806. Ramli Semmawi. "Urgensi Akad dalam Hukum Ekonomi Islam." Jurnal Ilmiah Al-Syir'ah 8, no. 2 (2010). Azila Ahmad Sarkawi. "Akad-akad Muamalah dalam Fiqh: Satu Analisis." Jurnal Syariah 6 (1998): 37-42. Ajeng Mar'atus Solihah. "Penerapan Akad Ijarah pada Pembiayaan Multijasa dalam Perspektif Hukum Islam." Az Zarqa': Jurnal Hukum Bisnis Islam 6, no. 1 (2014). Bagus Ahmadi. "Akad Bay', Ijarah dan Wadiah Perspektif Kompilasi Hukum Ekonomi Syariah (KHES).” Epistemé: Jurnal Pengembangan Ilmu Keislaman 7, no. 2 (2012): h. 311-336. 
tidak melaksanakan sebagaimana mestinya sehingga penyedia jasa tidak mendapatkan apa yang dijanjikan oleh pihak lawan.

Tulisan ini akan membahas penetapan dasar upah jasa pembajak sawah dan perbedaan besaran upah jasa pembajak sawah di Desa Klesem Kecamatan Kebonagung Kabupaten Pacitan. Terakhir tulisan ini akan membahas masalah wanprestasi pembajakan sawah dalam pandangan hukum Islam.

\section{Dasar Penetapan Upah Jasa Pembajak Sawah}

Ujrah atau upah dipahami sebagai sesuatu yang dijanjikan dan dibayar penyewa sebagai kompensasi atau pembayaran atas manfaat yang dinikmatinya. Pada prinsipnya semua yang dapat digunakan sebagai alat tukar dalam jual beli boleh digunakan untuk pembayaran dalam ijârah. ${ }^{14}$ Di samping itu, ujrah haruslah sesuatu yang bernilai dan diperbolehkan oleh syara' dan harus diketahui jumlahnya. ${ }^{15}$ Ujrah yang disyari'atkan diketahui jumlahnya oleh kedua belah pihak, baik dalam sewa-menyewa maupun upah-mengupah. ${ }^{16}$ Imbalan yang pantas menurut syara' adalah sesuatu yang bernilai dan terdapat keridaan antara kedua belah pihak. Dalam kaidah ushûliyah dijelaskan: ${ }^{17}$

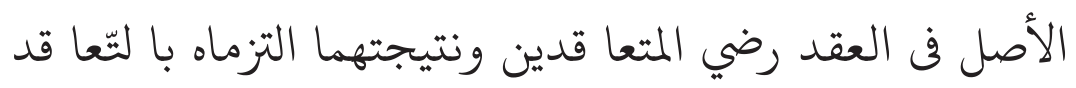

"Hukum Asal sesuatu dalam transaksi adalah keridhaan kedua belah pihak yang berakad, hasilnya adalah berlaku syahnya yang diakadkan".

Kaidah di atas menjelaskan bahwa keridaan dalam transaksi merupakan prinsip dalam transaksi. Oleh karena itu, transaksi barulah sah apabila didasarkan kepada keridaan kedua belah pihak. Artinya, tidak sah akad apabila salah satu pihak dalam keadaan terpaksa atau dipaksa atau juga merasa tertipu. Bisa saja ketika akad telah merasa saling meridai, tetapi kemudian salah satu pihak merasa tertipu, artinya

${ }^{14}$ Abdullah bin Muhammad Ath-Thayar, Ensiklopedia Fiqh Muamalah dalam Pandangan 4 Madzhab, trans. oleh Miftahul Khairi (Riyadh: Madarul-Wathan Lin-Nasyr, 2004), h. 318.

${ }^{15}$ Dimyauddin Djuwaini, Pengantar Figh Muamalah (Yogyakarta: Pustaka Pelajar, 2008), h. 159.

${ }^{16}$ Abdullah bin Muhammad Ath-Thayar, Ensiklopedia Fiqh Muamalah dalam Pandangan 4 Madzhab, h. 318.

${ }^{17}$ H. A. Zhazuli, Kaidah-Kaidah Fiqh (Jakarta: Kencana, 2007), h. 130-131. 
hilang keridaannya maka akad tersebut bisa batal. ${ }^{18}$

Dalam kenyataanya di lapangan, lokasi persawahan cukup jauh dari tempat tinggal pekerja dan bahkan jalan tempuh hanya bisa diakses dengan jalan kaki. ${ }^{19}$ Pihak penyedia jasa merasa ada ketidakseimbangan antara jasa yang diberikan dengan upah yang telah ditetapkan. Pihak penyedia jasa menuntut agar jasa yang dipakai di luar proses pembajakan harus diperhitungkan. Menurut penyedia jasa, penetapan upah dengan besaran 1 jam Rp. 40.000,00 itu hanya cocok diterapkan pada lokasi sawah yang tidak jauh dari pemukiman warga dan jalan tempuh mudah diakses. ${ }^{20}$ Pada waktu akad berlangsung, kedua belah pihak telah sepakat tidak ada penambahan upah. Namun ketika pekerjaan direalisasikan salah satu pihak merasa ada ketidakseimbangan atas upah jasa yang diterima.

Menetapkan standard upah yang adil bagi seorang pekerja sesuai dengan hukum Islam bukan perkara mudah. Kompleksitas permasalahannya terletak pada ukuran apa yang akan dipergunakan, dapat mentransformasikan konsep upah yang adil dalam dunia kerja. ${ }^{21}$ Dasar dan ukuran yang digunakan dalam penetapan upah jasa pembajak sawah di Desa Klesem adalah menggunakan perhitungan bahan bakar yang dipakai alat pembajak selama proses 'penggarukan'. Hitungan kalkulasinya

${ }^{18}$ H. A. Zhazuli, Kaidah-Kaidah Fiqh, h. 130-131.

${ }^{19}$ Hasil Observasi, Pacitan, 02 Nopember 2016.

${ }^{20}$ Wawancara dengan Bapak Sujito, (Penyedia Jasa Pembajak Sawah, Pacitan).

${ }^{21}$ H. A. Zhazuli, Kaidah-Kaidah Figh, h. 131. Maka diberbagai daerah memiliki kompleksitas tersendiri dalam merumuskan standardisasi pengupahan bagi para pekerja, lebih lengkapnya bisa dilihat dalam tulisan Michele Agustine, dan I. Ariawan. "Pemberlakuan UMK (Upah Minimum Kabupaten/Kota) terhadap Kesejahteraan Pekerja/Buruh.” Kertha Negara 1 (2013). Ninda Noviani Charysa. "Pengaruh Pertumbuhan Ekonomi dan Inflasi Terhadap Upah Minimum Regional di Kabupaten/Kota Provinsi Jawa Tengah Tahun 2008-2011.” Economics Development Analysis Journal 2, no. 4 (2013). Andi Neno Ariani. "Pengaruh Jumlah Usaha, Nilai Investasi dan Upah Minimum Terhadap Penyerapan Tenaga Kerja Pada Industri Kecil dan Menengah di Kabupaten Pinrang Tahun 2001-2011." Universitas Hasanuddin, Makassar (2013). Fuad Riyadi. "Sistem dan Strategi Pengupahan Perspektif Islam." Iqtishadia (Journal of Islamic Economics and Business) 8, no. 1 (2015). Dian Ferricha. "Peninjauan Upah Hukum Positif Perspektif Doktrin Ekonomi Islam Mengenai Upah Syariah." AnNisbah: Jurnal Ekonomi Syariah 2, no. 1 (2015): h. 295-318. Mansor Jusoh, Md Nor, dan Nor Ghani. “Tenaga Buruh dan Upah dalam Islam: Satu Pandangan Alternatif." Islamiyyat 27, no. 1 (2005). Sri Hery Susilowati. "Gejala Pergeseran Kelembagaan Upah pada Pertanian Padi Sawah." Dalam Forum Penelitian Agro Ekonomi, vol. 23, no. 1, h. 48-60. 2016. Neni Fitri Yana. "Konsep Upah Tenaga Kerja Menurut Perspektif Afzalur Rahman.” PhD diss., Universitas Islam Negeri Sultan Syarif Kasim Riau, 2010. Hudan Nasyiqin Muhammad. "Konsep Upah Menurut Sistem Ekonomi Kapitalis dan Sistem Ekonomi Islam.” PhD diss., STAIN Ponorogo, 2015. 
adalah per jamnya Rp. 40.000,00. Pada umumnya 1 jam menghabiskan 1-2 liter bensin, sedangkan harga bensin per liter Rp. 8.500,00. Pembajak menghabiskan 2 liter bensin x Rp. 8.500,00 = Rp. 17.000,00. Hitungan kasar pendapatan bersih dalam 1 jam adalah Rp. 40.000,00 - Rp. $17.000,00=$ Rp. $23.000,00$.

Pihak penyedia jasa melakukan perundingan dan pengkajian terlebih dahulu dengan pemilik sawah sebelum penetapan besaran upah ditentukan. Hasil dari penetepan upah tersebut kemudian diberitahukan kepada masyarakat petani setempat. ${ }^{22}$ Menurut sebagian pekerja dengan pendapatan upah rata-rata bersih Rp. 23.000,00 per jam tersebut telah memenuhi unsur kepatutan dan rasa keadilan, karena memang pembajakan sawah tidak mudah dan harus dengan tenaga yang ekstra, terlebih dengan medan sawah yang sempit tingkat kesulitan dan resiko beban kerja yang ditanggung cukup tinggi. ${ }^{23}$

Penetapan upah jasa pembajak sawah dan petani sejalan dengan penjelasan Hadith Riwayat Bukhari dan Muslim dari Ibnu Majah menyebutkan:

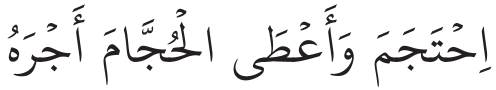

"Berbekamlah kamu, kemudian berikanlah upah kepada tukang bekam tersebut." 24

Hadis ini menjelaskan tata cara bagaimana melakukan akad Ijârah, khususnya terkait dengan penetapan besaran upah sewa. Besaran upah sewa (dalam hal ini jasa pembajak sawah) dalam kontrak perjanjian merupakan sesuatu yang telah disepakati kedua pihak sehingga tidak terjadinya perselisihan di kemudian hari. Kedua pihak yang bertransaksi harus menjelaskan hak dan kewajiban di antara keduanya untuk menghindari perselisihan. ${ }^{25}$

Prinsip utama penetapan upah adalah keadilan yang terletak pada kejelasan akad (transaksi) dan komitmen melaksanakan komitmen.

${ }^{22}$ Hasil Observasi, Pacitan, 02 Nopember 2016.

${ }^{23}$ Wawancara dengan Bapak Anwar Khusairi, (Penyedia Jasa Pembajak Sawah, Pacitan), 16 Desember 2016.

${ }^{24}$ Al-Imam Abu Abdullah bin Ismail al-Bukhari, Tarjamah Shahih Bukhari, trans. oleh Achmad Sunarto (Semarang: CV Asy Syifa', 1993), h. 18.

${ }^{25}$ Dimyauddin Djuwaini, Pengantar Fiqh Muamalah, h. 157. 
Akad dalam perburuhan adalah akad yang terjadi antara pekerja dengan pengusaha. Bagaimana upah yang akan diterima oleh pekerja harus jelas sebelum pekerjaan dilakukan yang meliputi besarnya upah dan tata cara pembayaran upah. Taqyuddin al-Nabhani mengajukan penyelesaian gaji dengan konsep ijârah, di mana ijârah adalah memanfaatkan jasa suatu kontrak. Apabila ijârah berhubungan dengan pekerja, maka yang dimanfaatkan adalah tenaganya. ${ }^{26}$

Menurutnya al-Nabhani, upah tersebut tidak didasarkan pada kebutuhan hidup. Ia mendasarkan upah pekerja pada jasa atau manfaat yang diberikan pekerja dengan perkiraan ahli terhadap jasa tersebut di tengah masyarakat. Jika upah telah disebutkan pada saat akad, maka upah yang berlaku adalah upah yang disebutkan, sedangkan jika upah belum disebutkan atau terjadi perselisihan di dalamnya, maka upah yang diberlakukan adalah upah yang sepadan. ${ }^{27}$

Dalam sebuah transaksi penyewaan jasa, setelah terjalinnya akad kedua pihak saling meridai dan kewajiban penetapan upah jasa sudah ditentukan, maka selanjutnya adalah melaksanakan tanggung jawab pekerjaan. Kaitannya dengan hal ini, maka terdapat kewajiban pembayaran upah jasa yang harus dipenuhi oleh pihak penyewa jasa atau pemilik lahan setelah pekerjaan itu dipenuhi. Seperti yang telah dijelaskan dalam fikih muamalah bahwa ajîr khâss berhak atas upah yang telah ditentukan bila ia telah menyerahkan dirinya kepada mustajir dan memenuhi pekerjaannya dalam waktu berlakunya perjanjian itu. ${ }^{28}$

Berdasarkan hadis Rasulullah Saw. yang diriwayatkan oleh Ibnu Majah, yang berbunyi:

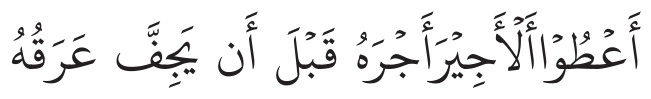

"Berikanlah upah kepada orang yang kamu pakai tenaganya sebelum kering keringatnya." 29

${ }^{26}$ Taqiyudin an-Nabbani, Membangun Sistem Ekonomi Alternatif Perspektif Islam, trans. oleh Moh. Maghfur Wachid (Surabaya: Risalah Gusti, 2009), h. 108.

${ }^{27}$ Taqiyudin an-Nabbani, Membangun Sistem Ekonomi Alternatif Perspektif Islam, h. 108.

${ }^{28}$ Thayar, Abdullah bin Muhammad Al-, Ensiklopedia Fiqh Muamalah dalam Pandangan 4 Madzhab, h. 318.

${ }^{29}$ Abu Abdullah Muhammad bin Yazid Ibnu Majah, Terjemah Sunan Ibnu Majah, trans. 
Hadis di atas berkaitan etika dalam melakukan akad ijârah, yakni memberikan pembayaran upah secepat mungkin. Relevansinya dengan praktik kontrak ijârah pada pembahasan ini adalah adanya keharusan untuk melakukan pembayaran uang sewa sesuai dengan kesepakatan atau batas waktu yang telah ditentukan, sejatinya pemberian upah tidak ditunda dari jadwal atau tenggang waktu yang telah disepakati. ${ }^{30}$

Pembayaran upah jasa pembajak sawah di Desa Klesem dilakukan sesuai dengan perjanjian dan kesepakatan bersama. Pemilik lahan memberikan upah pembajak pada waktu yang telah dijanjikan. Setiap pekerjaan pembajakan sawah, pemilik sawah langsung memberikan upahnya. Ada sebagian kecil yang membayar upah jasa lebih lambat, namun tidak ada maksud untuk memperlambat atau mengulur-ulur waktu pembayaran upah. Meskipun demikian hal tersebut dapat dipahami oleh kedua belah pihak, karena secara finansial pemilik sawah pasti mampu untuk membayar upah, dan biasanya hal tersebut sudah dipersiapkan sebelumnya. ${ }^{31}$

Hal ini sejalan dengan pendapat para ulama mazhab yang menyatakan bahwa jika ijârah itu suatu pekerjaan, maka pembayaran upahnya pada waktu berakhirnya pekerjaan. Bila tidak ada pekerjaan lain, jika akad sudah berlangsung dan tidak disyari'atkan mengenai pembayaran dan tidak ada ketentuan penangguhannya. Menurut Abû Hanifah wajib diserahkan upahnya secara berangsur sesuai dengan manfaat yang diterimanya. Menurut Imam Syafi'i dan Ahmad, sesungguhnya ia berhak dengan akad itu sendiri. Jika müir menyerahkan zat benda yang disewa kepada mustajir, ia berhak menerima bayarannya karena penyewa (mustajir) sudah menerima kegunaannya. ${ }^{32}$

Penulis menyimpulkan bahwa dasar penetapan upah jasa yang dilakukan pihak penyedia jasa dalam pembajakan sawah di Desa Klesem sudah sesuai dengan hukum Islam. Penetapan upah jasa oleh pihak penyedia jasa telah memperhatikan ketentuan-ketentuan dalam hukum Islam. Ketentuanketentuan tersebut di antaranya memperhatikan kejelasan dan keabsahan akad, saling meridai, dan sebelum menetapkan besaran upah keduanya

oleh Abdullah Shonhaji (Semarang: CV Asy Syifa', 1993), h. 4.

${ }^{30}$ Dimyauddin Djuwaini, Pengantar Fiqh Muamalah, h. 157.

${ }^{31}$ Wawancara dengan Bapak Anwar Khusairi, (Penyedia Jasa Pembajak Sawah, Pacitan).

32 Suhendi, Fiqh Muamalah, t.t., h. 121. 
melakukan perundingan terlebih dahulu. Penetapan upah jasa didasarkan pada perhitungan bahan bakar mesin traktor dengan tidak mendasarkan pada kebutuhan hidup dan pembayarannya dilakukan setelah pekerjaan selesai. Adapun tujuan dari penetapan upah jasa tersebut adalah agar terjadi keseimbangan dalam jasa yang dikeluarkan dengan upah jasa yang diberikan. Sehingga antara pihak penyedia jasa dengan pihak pemilik lahan sama-sama sepakat dengan segala ketentuan yang dibuat, tanpa ada salah satu pihak yang diuntungkan pihak lain merasa dirugikan.

\section{Perbedaan Besaran Upah Jasa Pembajak Sawah di Desa Klesem}

Terdapat tiga model mekanisme pengupahan karyawan atau pekerja, yaitu upah menurut waktu, upah menurut hasil dan upah premi. Setiap pekerjaan mempunyai standar pengupahan tersendiri dengan beragam sistem dan tata cara pengupahannya. Sedangkan pengupahan dalam jasa pembajak sawah di Desa Klesem ini menggunakan sistem upah menurut waktu. Berdasarkan upah yang telah ditetapkan per jam adalah Rp. 40.000,00.33 Namun demikian, dalam sistem pengupahan jasa pembajak sawah di Desa Klesem yang telah ditetapkan, terdapat perbedaan besaran upah jasa yang diberlakukan oleh pihak penyedia jasa kepada pihak pemilik lahan/petani.

Sebagian lokasi persawahan di Desa Klesem jauh dari pemukiman warga, dan hanya bisa diakses dengan jalan kaki karena daerahnya pegunungan dan perbukitan. Sedangkan keadaan tanahnya bervariasi, ada yang gempur, padat, lempung (tanah liat) dan bercampur batu 'grugus'. Biasanya jika persawahan lama tidak terairi oleh air hujan, tanahnya menjadi kering dan keras. Sebagian keadaan tanah terbungkus oleh rumput tebal (lebat) karena sebelumnya tanah tersebut dibiarkan setelah panen pertama. Keadaan semacam itu yang melatarbelakangi perbedaan besaran upah jasa yang diberlakukan dalam praktik jasa pembajak sawah di Desa Klesem.

Perbedaan besaran upah jasa pembajakan sawah disebabkan lokasinya yang jauh dari tempat tinggal pekerja dan jalannya hanya bisa diakses dengan jalan kaki saja. Penambahan besaran upah dari penyedia jasa didasarkan pertimbangan sebagai ganti perjalanan dan biaya transportasi. ${ }^{34}$ Di samping

\footnotetext{
${ }^{33}$ Hasil Observasi, Pacitan, 02 Nopember 2016.

${ }^{34}$ Wawancara dengan Bapak Jumari, (Penyedia Jasa Pembajak Sawah, Pacitan), 20 Januari 2017.
} 
itu, penyedia jasa mengalami kesulitan selama proses penggarukan tanah, juga risiko dan beban kerja yang ditanggungnya. ${ }^{35}$

Perbedaan besaran upah jasa pembajak sawah di Desa Klesem tidak menyimpang dari hukum Islam karena sesuai dengan sabda Rasulullah Saw. yang disampaikan oleh Imam al-Ghazâli di dalam kitabnya Ihyâ 'Ulûmuddin yang berbunyi:

\section{"Upah atau gaji melihat ukuran lelahnya suatu pekerjaan".}

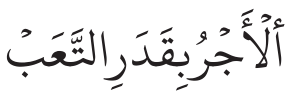

Besar kecilnya upah dalam suatu pekerjaan dapat dilihat dan diukur dari beberapa faktor. Salah satu faktor yang dapat mempengaruhi besar kecilnya upah dalam suatu pekerjaan adalah faktor jumlah pekerjaan atau tingkat kesulitan pekerjaan dan beban kerja serta besar kecilnya risiko pekerjaan. Faktor kewilayahan juga menjadi aspek yang ikut menentukan besar kecilnya upah, terkait dengan jauh dekatnya lokasi atau tempat kerja atau perbedaan wilayah penetapan upah. ${ }^{36}$

Penambahan besaran upah yang diberlakukan oleh pihak penyedia jasa terhadap pemilik lahan hanya berdasarkan kebijakan sepihak. Dalam hal ini yang mengambil kebijakan tersebut adalah pihak penyedia jasa. Dan biasanya penambahan penarikan upah jasa tersebut tidak disampaikan di awal ketika akad perjanjian berlangsung, akan tetapi disampaikan di akhir ketika pengerjaan telah selesai. ${ }^{37}$

Penambahan penarikan upah dari yang sudah ditetapkan akan berdampak pada ketidakpastian sistem pengupahan karena upah jasa yang harus diberikan kepada pekerja di luar perkiraan petani. Dalam arti ketidakpastian disebabkan terjadi dualisme sistem pengupahan yang diberlakukan. Dalam hal ini penyedia jasa mempunyai dua pilihan. Pertama, memberlakukan upah jasa yang telah ditetapkan (1 jam Rp 40.000,00). Kedua, menambah besaran upah jasa dari yang sudah ditetapkan.

Alasan pihak penyedia jasa meminta tambahan upah dari yang sudah

${ }^{35}$ Wawancara dengan Bapak Jumari, (Penyedia Jasa Pembajak Sawah, Pacitan).

${ }_{36} 18$ Februari 2017, m.hukumonline.com/klinik/detail/faktor-faktor-yang-dapatmenentukan-besar-kecilnya-upah.

${ }^{37}$ Wawancara dengan Bapak Agung Sulistyono, (Petani, Pacitan), 29 Januari 2017. 
ditetapkan sebagai ganti jasa perjalanan, transportasi. Hal ini dikhawatirkan terdapat unsur spekulasi yang dilakukan oleh pihak penyedia jasa. Bisa saja pihak penyedia jasa melakukan penarikan penambahan upah jasa sematamata sebagai ganti jasa perjalanan dan transportasi. Padahal hal itu tidak perlu dilakukan, terkecuali jika benar-benar membutuhkan biaya sebagai ganti jasa perjalanan dan transportasi. ${ }^{38}$

Penetapan tambahan upah secara sepihak bertentangan dengan prinsip dalam bermuamalah suka sama suka atau saling meridai. Dan hukum Islam melarang bermuamalah melakukan kezaliman, penipuan dan menghindari kompetisi yang tidak sehat. Hukum Islam mengutamakan kepentingan umum atau menetapkan kemaslahatan dan menghindari kemafsadatan bagi manusia. Hukum Islam disyariatkan dalam memelihara agama, memelihara jiwa, maka ketika bertransaksi harus dilandasi saling meridai. ${ }^{39}$

Sebagaimana dalam firman Allah Swt. dalam Alquran Surat al-Nisa': 29 yang artinya: "Hai orang-orang yang beriman, janganlah kamu saling memakan harta sesamamu dengan jalan yang batil, kecuali dengan jalan perniagaan yang berlaku dengan suka sama-suka di antara kamu dan janganlah kamu membunuh dirimu. Sesungguhnya Allah adalah Maha Penyayang kepadamu. ${ }^{40}$ Pesan yang terdapat dalam ayat tersebut adalah di dalam kegiatan bermuamalah hendaklah didasari oleh perbuatan suka sama suka, rela sama rela sehingga tidak ada pihak yang dirugikan baik pihak penyedia jasa maupun penyewa jasa, sehingga terciptalah transaksi yang adil. ${ }^{41}$

Kebebasan dalam suatu transaksi membutuhkan persetujuan bersama, kebersamaan dan kesepakatan dari kedua pihak yang melakukan kesepakatan jangan sampai keuntungan yang diperoleh satu pihak merupakan kerugian yang diderita oleh pihak lain. ${ }^{42}$ Seorang muslim harus melakukan segala transaksi dengan cara yang jelas, transparan dan adil. Dengan demikian dalam melaksanakan transaksi harus dilakukan

${ }^{38}$ Wawancara dengan Bapak Agung Sulistyono, (Petani, Pacitan).

${ }^{39}$ M. Ali Hasan, Berbagai Macam Transaksi dalam Islam; Fiqh Muamalah (Jakarta: PT Raja Grafindo Persada, 2004), h. 232.

${ }^{40}$ Yayasan Penyelenggara Penterjemah Alquran, Alquran dan Terjemahnya (Semarang: CV al-Waah, t.t.), h. 107.

${ }^{41}$ Yayasan Penyelenggara Penterjemah al-Qur'an, Alquran dan Terjemahnya, h. 107.

${ }^{42}$ Ahmad, Etika Bisnis dalam Islam, t.t., h. 96. 
secara mabrûr, yaitu transaksi yang di dalamnya terdapat kejujuran, lurus, benar tidak menipu, tidak khianat, dan tidak mendurhakai Allah Swt. ${ }^{43}$

Menurut penulis, perbedaan besaran upah jasa dalam praktik pembajak sawah di Desa Klesem ini tidak bertentangan dengan hukum Islam dan dalam praktiknya diperbolehkan. Sedangkan dalam praktiknya apabila dalam penambahan besaran upah jasa tersebut tidak atas dasar sukarela dan saling meridai antara kedua belah pihak, maka akad transaksi tidak sah dan akad transaksi menjadi gugur, sehingga hal ini bertentangan dengan hukum Islam.

\section{Wanprestasi dalam Jasa Pembajak Sawah}

Tercapainya kesepakatan merupakan unsur penting dalam kontrak, sebab kesepakatan yang menentukan munculnya kontrak dan perikatan sehingga lahirlah hak dan kewajiban. Para pihak menjadi terikat satu sama lain sebagaimana yang terdapat dalam kontrak yang telah mereka sepakati. Pelaksanaan isi perjanjian harus sesuai dengan term dan condition seperti yang telah disebutkan dalam perjanjian. Jika tidak dilaksanakan, maka akan menimbulkan kerugian, dan kerugian tersebut bisa terjadi karena kesalahan salah satu pihak atau bisa jadi di luar kesalahan para pihak dalam kontrak. ${ }^{44}$

Penduduk Desa Klesem menggantungkan pendapatan ekonomi dan usahanya dalam bidang pertanian. Dalam pengelolaan dan penggarapan lahan sawah, mereka sering menggunakan jasa para pemilik mesin traktor pembajak sawah. Para petani melakukan ini untuk memudahkan dan mempercepat proses penanaman padi. Inilah yang mendorong mereka untuk melakukan kegiatan muamalah dalam bentuk sewa-menyewa jasa (upah-mengupah)..$^{45}$

Terdapat beberapa permasalahan yang terjadi dalam praktik pembajakan sawah, di antaranya: ${ }^{46}$

\footnotetext{
${ }^{43}$ Ahmad, Etika Bisnis dalam Islam, h. 97.

${ }^{44}$ Ridwan Khariandy, Hukum Kontrak Indonesia (Yogyakarta: FH UII Press, 2014), h. 238.

${ }^{45}$ Hasil Observasi, Pacitan, 25 Januari 2017.

${ }^{46}$ Wawancara dengan Bapak Jumari, (Penyedia Jasa Pembajak Sawah, Pacitan).
} 


\section{Mengenai keterangan waktu berlakunya perjanjian}

Ada sebagian pemilik sawah jauh-jauh hari telah memesan kepada pembajak sawah untuk membajak sawahnya dan ada juga sebagian pemilik sawah seacara langsung meminta membajak sawahnya. Kemudian kedua belah pihak membuat akad perjanjian secara lisan tentang besaran upah dan waktu penggarapan sawah. Sebagian pekerja menentukan kapan waktunya dengan menyebutkan hari atau minggu. Dan ada juga sebagian penyedia jasa tidak menentukan kepastian waktu, misalnya hanya mengatakan "pembajakan atau penggarapannya setelah selesai penggarapan sawahnya Bapak Khamim”. ${ }^{47}$

Biasanya pihak pemilik sawah hanya menyebutkan lokasi sawah pada saat terjalinnya akad, tanpa ada pengecekan secara langsung oleh pihak penyedia jasa ke lokasi lahan sawah. Adapun waktu penggarapan belum ada kepastian tentang kapan waktunya sawah akan dibajak ketika berakad cenderung ditentukan sepihak, di mana yang mengetahui kepastiannya kapan akan dikerjakan hanya pihak penyedia jasa. ${ }^{48}$

Dalam hukum Islam, perjanjian kerja tertuju kepada penyewaan jasa manusia atau ajîr khâss, lama waktu berlakunya perjanjian harus dijelaskan, dengan akibat bila waktu tidak jelas, perjanjian dipandang rusak (fâsid), sebab faktor waktu dalam perjanjian tersebut menjadi ukuran besarnya jasa yang diinginkan. Tanpa menyebutkan waktu yang diperlukan, objek perjanjian menjadi kabur, bahkan tidak diketahui dengan pasti dan mudah menimbulkan sengketa di belakang hari. ${ }^{49}$ Dan bila pekerjaan tersebut sudah tidak jelas, maka hukumnya tidak sah. ${ }^{50}$

Menurut Bapak Turijan, ketidaktepatan waktu dari pihak penyedia jasa dikarenakan ada permintaan mendadak dari pemilik lahan yang lain di mana lokasi sawahnya berdekatan dengan lokasi sawah yang sedang dikerjakan, sehingga permintaan yang lebih dulu terabaikan. Hal itu juga disebabkan lokasi sawah yang satu dengan lainnya saling berjauhan, sehingga tidak memungkinkan pekerja berpindah-pindah

\footnotetext{
${ }^{47}$ Wawancara dengan Bapak Jumari, (Penyedia Jasa Pembajak Sawah, Pacitan).

${ }^{48}$ Hasil Observasi, Pacitan, 25 Januari 2017.

49 Ahmad Azhar Basyir, Hukum Zakat (Yogyakarta: Majelis Pustaka Pimpinan Pusat Muhammadiyah, 1997), h. 34-36.

${ }^{50}$ Taqiyudin an-Nabbani, Membangun Sistem Ekonomi Alternatif Perspektif Islam, h. 88.
} 
dan mengharuskan untuk diselesaikannya lokasi sawah yang berdekatan meskipun permintaanya mendadak..$^{51}$

Berdasarkan uraian di atas, pihak penyedia jasa dalam praktik pembajakan sawah di Desa Klesem telah melakukan wanprestasi atas perjanjian yang disepakati. Bentuk wanprestasi tersebut adalah pekerja belum melakukan pekerjaan sama sekali sesuai dengan akad perjanjian dan apabila melakukan pekerjaan waktunya terlambat atau tidak memenuhi prestasi.

Wanprestasi dalam hukum perjanjian mempunyai makna bahwa debitur tidak melaksanakan kewajiban prestasinya atau tidak melaksanakan sebagaimana mestinya sehingga kreditur tidak mendapatkan apa yang dijanjikan oleh pihak lawan. ${ }^{52}$ Adapun pengertian umum tentang wanprestasi adalah pelaksanaan kewajiban yang tidak tepat pada waktunya atau dilakukan tidak menurut selayaknya. ${ }^{53}$

Menurut Dedi Ismatullah, wanprestasi artinya tidak memenuhi sesuatu yang diwajibkan, seperti yang telah ditetapkan dalam perikatan. Tidak terpenuhinya kewajiban oleh debitur disebabkan dua kemungkinan alasan yaitu: ${ }^{54}$

a. Karena kesalahan debitur, baik dengan sengaja atau tidak dipenuhinya kewajiban maupun karena kelalaian;

b. Karena keadaan memaksa (overmacht), force majure, artinya di luar kemampuan debitur. ${ }^{55}$

Terdapat empat unsur dalam wanprestasi yakni pertama, tidak melakukan apa yang sanggup dilakukannya. Kedua, melakukan apa yang diperjanjikan tetapi tidak sebagaimana apa yang diperjanjikan. Ketiga, melakukan sesuatu yang menurut perjanjian tidak boleh dilakukan. Keempat, melakukan apa yang diperjanjikan tetapi terlambat. ${ }^{56}$ 2016.

${ }^{51}$ Wawancara dengan Bapak Turijan, (Penyedia Jasa Pembajak Sawah, Pacitan), 21 Desember

${ }^{52}$ Ridwan Khariandy, Hukum Kontrak Indonesia, h. 278.

${ }^{53}$ Ridwan Khariandy, Hukum Kontrak Indonesia, h. 278.

${ }^{54}$ Dedi Ismatullah, Hukum Perikatan: Dilengkapai Hukum Perikatan dalam Islam (Bandung: Pustaka Setia, 2011), h. 103.

${ }^{55}$ Dedi Ismatullah, Hukum Perikatan: Dilengkapai Hukum Perikatan dalam Islam, h. 103.

56 Salim, Hukum Kontrak Teori dan Teknik Penyusunan Kontrak (Jakarta: Sinar Grafika, 2003), h. 98. 
Jika wanprestasi terjadi masih di dalam batas kemampuan manusia, berupa tidak berprestasi sama sekali, berprestasi tidak sempurna, berprestasi tidak tepat waktu, atau melakukan segala sesuatu yang dilarang dalam perjanjian. Maka adanya risiko lebih disebabkan oleh adanya keadaan atau situasi di mana memang debitur mustahil untuk memenuhi prestasi.

Menurut penulis, mengenai wanprestasi yang dilakukan oleh pekerja pembajak sawah di Desa Klesem dalam hukum Islam tidak diperbolehkan dan dilarang karena dipandang dapat merugikan pihak lain yang melakukan perjanjian, yakni pemilk sawah. Larangan tersebut dijelaskan dalam Alquran Surat al-Maidah ayat 1, yang artinya: ${ }^{57}$

"Hai orang-orang yang beriman, penuhilah akad-akad itu, dihalalkan bagimu binatang ternak, kecuali yang akan dibacakan kepadamu. (Demikian itu) dengan tidak menghalalkan berburu ketika kamu sedang mengerjakan haji. Sesungguhnya Allah menetapkan hukum-hukum menurut yang dikehendaki-Nya." ${ }^{58}$

Kata (أوفوا) aufû, yang berarti “memberikan sesuatu dengan sempurna”, perintah ini menunjukkan betapa Alquran menekankan perlunya memenuhi suatu akad dalam segala bentuk dan maknanya dengan pemenuhan sempurna, kalau perlu melebihkan dari yang seharusnya, serta mengecam mereka yang menyia-nyiakannya. Ini karena rasa aman dan bahagia manusia secara pribadi atau kolektif, tidak dapat terpenuhi kecuali bila mereka memenuhi ikatan-ikatan perjanjian yang mereka jalin. ${ }^{59}$

Pesan yang disampaikan dari ayat tersebut bahwa setiap mukmin berkewajiban menunaikan apa yang telah ia janjikan dan diakadkan baik berupa perkataan maupun perbuatan. Allah memeperintahkan seacara tegas dalam Alquran kewajiban seorang muslim memenuhi akad, walaupun hal tersebut merugikannya. ${ }^{60}$ Dalam ayat lain Q.s. Ali Imran ayat 76, Allah juga menegaskan: "Sebenarnya siapa saja yang menepati janji (yang dibuatnya) dan bertakwa, maka sesungguhnya Allah menyukai orang-orang yang bertakwa." ${ }^{61}$

${ }^{57}$ Yayasan Penyelenggara Penterjemah Alquran, Alquran dan Terjemahnya, h. 141.

${ }^{58}$ Akad (perjanjian) mencakup: janji prasetia seorang hamba kepada Allah Swt. dan perjanjian yang dibuat oleh manusia dalam pergaulan sesamanya.

${ }^{59}$ M. Quraish Shihab, Tafsir al-Misbah (Ciputat: Lentera Hati, 2001), h. 7.

${ }^{60}$ M. Quraish Shihab, Tafsir al-Misbah, h. 7.

${ }^{61}$ Yayasan Penyelenggara Penterjemah Alquran, Alquran dan Terjemahnya, h. 74. Maksudnya 
Istilah 'ahd dalam Alquran mengacu kepada pernyataan seseorang untuk mengerjakan sesuatu atau untuk tidak mengerjakan sesuatu. ${ }^{62}$ Orang yang memberikan persetujuan dalam kontrak sebenarnya berarti bahwa mereka memang menyadari dan menghendaki adanya kontrak itu serta menghendaki pula akibat hukum yang timbul dari kontrak itu. Lazimnya, semua persetujuan dalam kontrak memiliki kekuatan mengikat bagi para pihak dalam kontrak tersebut, dengan demikian mestinya isi persetujuan tersebut harus selalu dilaksanakan. Jika hal tersebut sungguh terlaksana, maka akan terwujud kehidupan yang tertib dan adil yang dirasakan oleh para pihak.

\section{Pembatalan perjanjian secara sepihak oleh pemilik lahan sawah}

Pembatalan perjanjian secara sepihak berawal dari rasa khawatir dan rasa kecewa yang dirasakan oleh pihak pemilik lahan disebabkan waktu pekerjaan yang tidak pasti dan ketidaktepatan waktu pengerjaan. Seperti yang pernah dialami oleh bapak Tumadi, ia merasa khawatir sawahnya tidak segera digarap atau dibajak, akhirnya memutuskan secara sepihak untuk menggarap sawahnya sendiri. Pembatalan tersebut dilakukan tanpa kesepakatan kedua belah pihak dan bahkan ada yang tanpa pemberitahuan terlebih dahulu dengan pihak penyedia jasa. Penggarapan dilakukan dengan cara yang masih tradisional, dengan memakai alat bajak dan cangkul yang dihasilkan dari tenaga manusia. ${ }^{63}$

Permasalahan yang sama pernah dialami oleh bapak Saman, sebelumnya sudah ada kesepakatan waktu pengerjaan di awal akad perjanjian. Pada waktu yang telah ditentukan, ternyata pihak penyedia jasa tidak memenuhi perjanjian. Bapak Saman mencoba mengkonfirmasi pihak penyedia jasa, kenapa penyedia jasa tidak memenuhi perjanjian dengan tepat waktu. Jawaban dari penyedia jasa, pada waktu yang sama masih mengerjakan sawah milik orang lain. Ketika ditunggu-tunggu sawahnya tidak kunjung dikerjakan, akhirnya bapak Saman memutuskan secara sepihak membatalkan akad perjanjian dan memilih untuk menyewa jasa pembajak lain. ${ }^{64}$

janji yang telah dibuat seseorang baik terhadap sesama manusia maupun terhadap Allah Swt.

${ }^{62}$ Suhendi, Fiqh Muamalah, h. 45.

${ }^{63}$ Wawancara dengan Bapak Tumadi, (Pemilik lahan sawah, Pacitan), 19 Desember 2016.

${ }^{64}$ Wawancara dengan Bapak Tumadi, (Pemilik lahan sawah, Pacitan). 
Pada dasarnya perjanjian sewa-menyewa merupakan perjanjian di mana masing-masing pihak yang terikat dalam perjanjian itu tidak mempunyai hak untuk membatalkan perjanjian (tidak mempunyai hak fasakh), karena jenis perjanjian ini termasuk perjanjian timbal balik. Sebagaimana diketahui bahwa perjanjian timbal balik yang dibuat secara sah tidak dapat dibatalkan secara sepihak, melainkan harus dengan kesepakatan. ${ }^{65}$ Ijârah adalah jenis akad lazim, yaitu akad yang tidak membolehkan adanya fasakh pada salah satu pihak, karena ijârah merupakan akad pertukaran, kecuali bila didapati hal-hal yang mewajibkan fasakh. ${ }^{66}$

Menurut ulama madzhab Malikiyah, Syafi'iyah dan Hanabilah bahwa transaksi ijârah harus diketahui dan dihadiri oleh kedua pihak. Masing-masing tidak bisa membatalkan perjanjian secara sepihak, kecuali ada alasan untuk itu, seperti barang yang disewa mengandung cacat. Tentang pernyataan bahwa salah satu pihak tidak boleh membatalkan transaksi ijârah, dimaksudkan agar masing-masing terhindar dari sifatsifat munafik, karena mereka membatalkan apa yang telah disepakati. Sedangkan menurut Abû Hanifah boleh saja membatalkan akad ijârah, dengan alasan tertentu, meski alasan tersebut dari pihak penyewa. Sebab, transaksi tersebut mesti dan seharusnya dilakukan atas dasar syarat-syarat yang dapat menghindari segala kemungkinan yang tidak diinginkan. ${ }^{67}$

Menurut penulis, praktik jasa pembajak sawah di Desa Klesem tidak sesuai dengan Hukum Islam. Berdasarkan pemaparan data di atas menunjukkan bahwa praktik jasa pembajak sawah tersebut terdapat wanprestasi oleh pihak penyedia jasa. Di mana bentuk wanprestasi tersebut adalah pekerja belum melakukan pekerjaan sama sekali sesuai dengan akad yang diperjanjikan dan apabila melakukan pekerjaan waktunya terlambat.

Adapun mengenai pembatalan atau pemutusan secara sepihak yang dilakukan oleh pihak pemilik lahan sawah/petani di Desa Klesem juga tidak sesuai dengan hukum Islam. Berdasarkan keterangan data di atas, pemilik lahan sawah dalam memutuskan akad perjanjian dilakukan secara sepihak dan tidak dengan kesepakatan terlebih dahulu. Agar pembatalan dan pemutusan sesuai dengan hukum Islam, antara kedua belah pihak

\footnotetext{
${ }^{65}$ Anshori, Hukum Perjanjian, t.t., h. 75.

${ }^{66}$ Suhendi, Fiqh Muamalah, h. 122.

${ }^{67}$ Ach. Khudori Soleh, Fiqh Kontekstual (Perspektif Sufi-Falsafi) (Jakarta: PT. Pertja, 1999), h. 99.
} 
harus membuat kesepakatan terlebih dahulu tentang pembatalan atau pemutusan kontrak ijârah, atau dengan jalan penyelesaian yang telah ditentukan oleh syari'at agama Islam.

\section{Penutup}

Tinjauan hukum Islam terhadap dasar penetapan besaran upah jasa jasa pembajak sawah di Desa Klesem Kecamatan Kebonagung Kabupaten Pacitan telah sesuai dengan hukum Islam. Penetapan upah yang ditentukan oleh pihak penyedia jasa telah memperhatikan ketentuan-ketentuan dalam hukum Islam. Ketentuan-ketentuan tersebut di antaranya, memperhatikan kejelasan dan keabsahan dalam berakad sehingga penyedia jasa dan petani saling meridai. Pihak penyedia jasa melakukan pengkajian dan musyawarah terlebih dahulu dengan petani sebelum menetapkan besaran upah.

Tinjauan Hukum Islam terhadap penambahan besaran upah jasa pembajak sawah di Desa Klesem Kecamatan Kebonagung Kabupaten Pacitan tidak bertentangan dengan hukum Islam dan dalam praktiknya diperbolehkan. Apabila dalam penambahan besaran upah jasa tersebut tidak atas dasar sukarela dan saling meridai antara kedua belah pihak, maka akad transaksi tidak sah dan akad transaksi menjadi gugur. Sehingga hal ini bertentangan dengan Hukum Islam.

Tinjauan hukum Islam terhadap wanprestasi jasa pembajak sawah di Desa Klesem Kecamatan Kebonagung Kabupaten Pacitan tidak sesuai dengan Hukum Islam. Dalam praktik pembajakan terdapat wanprestasi oleh pihak penyedia jasa. Bentuk wanprestasi tersebut adalah pekerja belum melakukan pekerjaan sama sekali sesuai dengan akad yang dijanjikan dan apabila melakukan pekerjaan waktunya terlambat. Adapun mengenai pembatalan atau pemutusan secara sepihak yang dilakukan oleh pihak petani juga tidak sesuai dengan hukum Islam. Petani memutuskan akad perjanjian secara sepihak dan tidak melibatkan pihak penyedia jasa.

\section{Pustaka Acuan}

Atmeh, Muhannad A., and Jamal Abdel-Rahman Abu-Serdaneh. "A Proposed Model for Accounting Treatment of Ijarah." International Journal of Business and Management 7, no. 18 (2012): 49. 
Ahmad, Nursilah, and Syazwani Abd Rahim. "Sukuk Ijarah vs. Sukuk Musyarakah: Investigating Post-Crisis Stock Market Reactions,"." International Journal of Humanities and Management Sci-ences (IJHMS) 1, no. 1 (2013).

Ahmad. Etika Bisnis dalam Islam, t.t.

Ahmadi, Bagus. "Akad Bay', Ijarah dan Wadi'ah Perspektif Kompilasi Hukum Ekonomi Syariah (KHES).” Epistemé: Jurnal Pengembangan Ilmu Keislaman 7, no. 2 (2012): 311-336.

Agustine, Michele, dan I. Ariawan. "Pemberlakuan UMK (Upah Minimum Kabupaten/Kota) terhadap Kesejahteraan Pekerja/Buruh.” Kertha Negara 1 (2013).

Anshori. Hukum Perjanjian, t.t.

Amin, Hanudin. "Al-Ijarah Thumma Al-Bay Facility in Labuan Car Markets: An Application of Structural Equation Model.” Labuan e-Journal of Muamalat and Society 4 (2010): 45-57.

Ameer, Muhammad Haroon, and Muhammad Saud Ansari. "Islamic Banking: Ijarah and Conventional Leasing." Developing Country Studies 4, no. 9 (2014): 126-129.

Anto, M.B. Hendrie. Pengantar Ekonomika Mikro Islami. Yogyakarta: Ekonosia, 2003.

Ariani, Andi Neno. "Pengaruh Jumlah Usaha, Nilai Investasi dan Upah Minimum Terhadap Penyerapan Tenaga Kerja Pada Industri Kecil dan Menengah di Kabupaten Pinrang Tahun 2001-2011.” Universitas Hasanuddin, Makassar (2013).

Basyir, Ahmad Azhar Hukum Zakat. Yogyakarta: Majelis Pustaka Pimpinan Pusat Muhammadiyah, 1997.

Bukhari, Al-Imam Abu Abdullah bin Ismail al-. Tarjamah Shahih Bukhari. Diterjemahkan oleh Achmad Sunarto. Semarang: CV Asy Syifa', 1993.

Charysa, Ninda Noviani. "Pengaruh Pertumbuhan Ekonomi dan Inflasi Terhadap Upah Minimum Regional di Kabupaten/Kota Provinsi Jawa Tengah Tahun 2008-2011.” Economics Development Analysis Journal 2, no. 4 (2013). 
Djuwaini, Dimyauddin. Pengantar Fiqh Muamalah. Yogyakarta: Pustaka Pelajar, 2008.

Ferricha, Dian. "Peninjauan Upah Hukum Positif Perspektif Doktrin Ekonomi Islam Mengenai Upah Syariah.” An-Nisbah: Jurnal Ekonomi Syariah 2, no. 1 (2015): 295-318.

Gupta, Namrata. "Differences in Accounting Treatment of Ijarah: A Case Study of UAE Islamic Banks." International Journal of Islamic and Middle Eastern Finance and Management 8, no. 3 (2015): 369-379. Hasan, M. Ali. Berbagai Macam Transaksi dalam Islam; Figh Muamalah. Jakarta: PT Raja Grafindo Persada, 2004.

Helmi Karim. Fiqh Muamalah. Jakarta: PT Raja Grafindo Persada, 1997. Huda, Qomarul. Fiqh Muamalah. Yogyakarta: Teras, 2011.

m.hukumonline.com/klinik/detail/faktor-faktor-yang-dapat-menentukanbesar-kecilnya-upah.

Ibn Majah, Abû Abdullah Muhammad bin Yazid. Terjemah Sunan Ibnu Majah. Diterjemahkan oleh Abdullah Shonhaji. Semarang: CV Asy Syifa', 1993.

Ismatullah, Dedi. Hukum Perikatan: Dilengkapai Hukum Perikatan dalam Islam. Bandung: Pustaka Setia, 2011.

Jamilah Abdul Jalil, Mariam, and Zuriah Abdul Rahman. "Sukuk Investment: Comparison of the Profits oObtained By Using Ijarah and Musharakah Mutanaqisah Principles With Long-Term Tenure." Qualitative Research in Financial Markets 4, no. 2/3 (2012): 206-227.

Jusmaliani. Teori Ekonomi dalam Islam. Yogyakarta: Kreasi Kencana, 2005. Jusoh, Mansor, Md Nor, dan Nor Ghani. "Tenaga Buruh dan Upah dalam Islam: Satu Pandangan Alternatif." Islamiyyat 27, no. 1 (2005). Khariandy, Ridwan. Hukum Kontrak Indonesia. Yogyakarta: FH UII Press, 2014.

Muhamed, Nurul Aini, and Rafisah Mat Radzi. "Implication of Sukuk Structuring: The Comparison on the Structure of Asset Based and Asset Backed Ijarah Sukuk." In 2nd International Conference on Business and Economic Research (2nd ICBER 2011) Proceeding, no. 2011-466. 2011. 
Muhammad, Hudan Nasyiqin. "Konsep Upah Menurut Sistem Ekonomi Kapitalis dan Sistem Ekonomi Islam.” PhD diss., STAIN Ponorogo, 2015.

Nabbani, Taqiyudin al-. Membangun Sistem Ekonomi Alternatif Perspektif Islam. Diterjemahkan oleh Moh. Maghfur Wachid. Surabaya: Risalah Gusti, 2009.

Rahman, Afzalur Doktrin Ekonomi Islam. 2. Yogyakarta: PT. Dana Bhakti Wakaf, 1995.

Rachmawati, Eka Nuraini. "Akad Jual Beli dalam Perspektif Fikih dan Praktiknya di Pasar Modal Indonesia." Al-'Adalah 12, no. 2 (2016): 785-806.

Ramli, Razli, and Hasleenda Onn. Islamic Hire-purchase (Ijarah Thumma Al-Bai-AiTab): The Handbook. Islamic Banking \& Finance Institute Malaysia Sdn Bhd, 2007.

Riyadi, Fuad. "Sistem dan Strategi Pengupahan Perspektif Islam." Iqtishadia (Journal of Islamic Economics and Business) 8, no. 1 (2015).

Salim. Hukum Kontrak Teori dan Teknik Penyusunan Kontrak. Jakarta: Sinar Grafika, 2003.

Sarkawi, Azila Ahmad. "Akad-akad Muamalah dalam Fiqh: Satu Analisis." Jurnal Syariah 6 (1998): 37-42.

Semmawi, Ramli. “Urgensi Akad dalam Hukum Ekonomi Islam.” Jurnal Ilmiah Al-Syir'ah 8, no. 2 (2010).

Siswantoro, Dodik. "Analysis of the First Ijarah Sukuk Default in Indonesia: How Could It Be?.” International Journal of Islamic Banking \& Finance 3, no. 2 (2013): 1-15.

Suhendi. Fiqh Muamalah, t.t.

Susilowati, Sri Hery. "Gejala Pergeseran Kelembagaan Upah pada Pertanian Padi Sawah.” Dalam Forum Penelitian Agro Ekonomi, vol. 23, no. 1, h. 48-60. 2016.

Shihab, M. Quraish. Tafsir al-Misbah. Ciputat: Lentera Hati, 2001. Soleh, Ach. Khudori. Fiqh Kontekstual (Perspektif Sufi-Falsafi). Jakarta: PT. Pertja, 1999. 
Solihah, Ajeng Mar'atus. "Penerapan Akad Ijarah pada Pembiayaan Multijasa dalam Perspektif Hukum Islam." Az Zarqa: Jurnal Hukum Bisnis Islam 6, no. 1 (2014).

Syarifuddin, Amir. Garis-garis Besar Fiqh. Jakarta: Prenada Media, 2003. Thayar. Abdullah bin Muhammad al-. Ensiklopedia Fiqh Muamalah dalam Pandangan 4 Madzhab. Diterjemahkan oleh Miftahul Khairi. Riyadh: Madarul-Wathan Lin-Nasyr, 2004.

Vejzagic, Mirza. "Ijarah Muntahia Bittamleek (IMB): A Risk Management Perspective." Merit Research Journal of Accounting, Auditing, Economics and Finance Vol. 2 (1)(2014): 001-007.

Yusoff, Remali, and Dayang Norainie Awang Masri. "Selection Factors of the Acceptance Al-Ijarah Thumma Al Bay (AITAB) in Shah Alam." In Kertas kerja dibentangkan di 5th Islamic Economics System Conference (iECONS 2013), h. 4-5. 2013.

Yayasan Penyelenggara Penterjemah al-Qur'an. al-Qur'an dan Terjemahnya. Semarang: CV al-Waah, t.t.

Yana, Neni Fitri. "Konsep Upah Tenaga Kerja Menurut Perspektif Afzalur Rahman.” PhD diss., Universitas Islam Negeri Sultan Syarif Kasim Riau, 2010.

Yulianti, Rahmani Timorita. "Asas-Asas Perjanjian (Akad) dalam Hukum Kontrak Syari'ah." La_Riba 2, no. 1 (2008): 91-107.

Zafar, Fahad. "Ijarah Contract: A Practical Dilemma." Journal of Islamic Accounting and Business Research 3, no. 1 (2012): 67-69.

Zhazuli, H. A. Kaidah-Kaidah Fiqh. Jakarta: Kencana, 2007.

\section{Wawancara}

Agung Sulistyono, (Petani, Pacitan), 29 Januari 2017.

Anwar Khusairi, (Penyedia Jasa Pembajak Sawah, Pacitan), 16 Desember 2016.

Bapak Sujito, (Penyedia Jasa Pembajak Sawah, Pacitan), 11 Januari 2017. Hasil Observasi, Pacitan, 02 Nopember 2016.

Hasil Observasi, Pacitan, 25 Januari 2017. 
Hasil Observasi, Pacitan, 27 November 2016.

Jumari, (Penyedia Jasa Pembajak Sawah, Pacitan), 20 Januari 2017.

Tumadi, (Pemilik lahan sawah, Pacitan), 19 Desember 2016.

Turijan, (Penyedia Jasa Pembajak Sawah, Pacitan), 21 Desember 2016.

Wawancara dengan Bapak Agung Sulistyono, (Petani, Pacitan, Pukul 19.25 WIB, Hari Minggu, Tanggal 29 Januari 2017).

Wawancara dengan Bapak Anwar Khusairi, (Penyedia Jasa Pembajak Sawah, Pacitan, Pukul 13.00 WIB, Hari Rabu, Tanggal 16 Desember 2016).

Wawancara dengan Bapak Jumari, (Penyedia Jasa Pembajak Sawah, Pacitan, Pukul 17.20 WIB, Hari Jum'at, Tanggal 20 Januari 2017). Wawancara dengan Bapak Sujito, (Penyedia Jasa Pembajak Sawah, Pacitan, Pukul 09.30 WIB, Hari Rabu, Tanggal 11 Januari 2017).

Wawancara dengan Bapak Tumadi, (Pemilik lahan sawah, Pacitan, Pukul 10.40 WIB, Hari Selasa, Tanggal 20 Desember 2016).

Wawancara dengan Bapak Turijan, (Penyedia Jasa Pembajak Sawah, Pacitan, Pukul 14.00 WIB, Hari Rabu, Tanggal 21 Desember 2016). 